\title{
THE REPRESENTATION OF SECURITY-HOLDERS' INTERESTS UNDER SECTION 77
}

\author{
WiLLIAM G. FennelL *
}

Protective committees, and fees charged in corporate reorganizations, in general, have long been the subject of debate in and out of Congress ${ }^{1}$ and have since 1935 become the subject of federal regulation. So far, however, strict regulation has been confined to two fields, namely, railroad ${ }^{2}$ and public utility reorganizations; ${ }^{3}$ and the protective committees in other fields of corporate reorganization have been left to the mild (and perhaps inadequate) regulation of the courts, first, under the provisions of Section $7 ; B^{5}$ and now, Chapter $X^{0}$ of the Bankruptcy Act, coupled with the "disciosure" provisions of the Securities Act and the Securities Exchange Act. ${ }^{8}$ It will be profitable to consider and to contrast the two radically different systems of regulation now effective as to railroad committees and public utility committees; to appraise the benefits or faults of the two systems; to consider whether the administration of regulation by the Interstate Commerce Commission of committees under Section 77 is achieving the reforms at which Congress aimed; to determine whether adequate representation of security-holders' interests is, and can be, effectuated under present conditions, and finally to see if there is room for improvement in the present systems of regulation.

But before considering these questions, there is a fundamental one which needs to be answered. That is, is there any place, or any need, for the protective committee under present methods of railroad reorganization, as contrasted with the "old" equity receivership?

\section{The Role of the Protective Commatree under Section 77}

In equity receivership, the protective committee was not only an adjunct, it was in fact the main-spring of the proceeding. As is well known, the customary pattern

- B.A., 1930, LL.B., 1933, Yale University. Member of the New York Bar, associated with the firm of Cadwalader, Wickersham \& Taft. Author of Protective Committees and Deposit Agreements in Railroad Reorganizations (1939) 49 YALE L. J. 224.

79 Cosc. Rec. 14231 (1935): 81 Cosc. Rec. 12163-12164 (1937); Sen. Rep. No. 1336, 74th Cong., Ist Sess. (1935); H. R. Rep. No. 1283, 74th Cong. 1st Sess. (1935); Lowentrul, The Investox Pays (1933); Douglas, Protective Committees in Railroad Reorganizations (1934) 47 HARv. L. Rev. 565.

49 Stat. 923-975 (1935), 11 U. S. C. $\$ 205$ (p) (Supp. 1938).

49 Star. 803 (1935), 15 U. S. C. $5979 \mathrm{k}$ (g), 79 r (c) (Supp. 1939).

- Fortas, The Securities Act and Corporate Reorganizations (1937) 4 LAw \& Contemp. Prob, $218,228$.

- 4 S Stat. 912 (1934), 11 U. S. C. $\$ 207$. 52 Star. 895 (1938), 11 U. S. C. \$5611-613.

i 4 Stat. 74 (1933), in U. S. C. C. $2 A$ (Supp. 1939); see particularly S77c (10).

${ }_{48}$ Stat. 88I (1934), 15 U. S. C. C. 2 B (Supp. 1939). 
was the so-called "friendly receivership"; a protective committee was organized to represent the secured creditors; and a bargain would, if possible, be struck with the equity, with which in many, if not most instances, the creditors' committee was on the most friendly terms arising from banker or other relationships of the sort. (After the Boyd case ${ }^{9}$ the creditors had to be careful to afford priority to unsecured creditors, but in most cases this diffculty was surmounted.) Thereafter, the committee, or a corporation organized by it, purchased at a foreclosure sale the property in receivership. The committee, perhaps by then metamorphosed into Reorganiza, tion Managers, thereupon carried out the "plan" and distributed the securities. In a railroad receivership, approval of the issuance of securities contemplated by the plan had to be obtained, after $x 920$, from the I. C. C. under Section $20 \mathrm{~A}$ of the Transportation Act, ${ }^{10}$ but otherwise the pattern was the same and the point I emphasize is clear: that the committee was the main-spring of such a "reorganization." And from its very character as such other results flowed. Because its function was to purchase at foreclosure, the committee had to know exactly what creditors it represented, and it had to have title and absolute control of the creditors' indicia of title, i.e., the deposited securities. It needed this to know, in the first place, what it could bid at the foreclosure sale and how much money it would have to put up to pay dissenters. Thus, a protective committee had to have the bonds deposited with it, had to issue certificates of deposit, and had to employ depositaries, and perhaps subdepositaries; and, rightly or wrongly, it was customary to vest a great amount of control over deposited securities with the committee.

Contrast this picture with the situation under Section 77 . The need for protective committees in Section 77 reorganizations is pragmatically demonstrated by the fact that they have continued to be organized and have functioned effectively in such reorganizations. But undeniably the functions of the protective committee have changed by reason of the methods of statutory reorganization set up by Section 77. The committee's chief function now is in connection with the promulgation of a plan of reorganization and the submission of such plan to the I. C. C. Depending upon the security it represents, the committee may prepare, file and defend a plan of its own; or it may be content (and thereby fulfill its function adequately), to scrutinize, defend, or oppose, other plans, including the debtor's. Upon a plan's adoption by the Commission and approval of it by the court, the committee may advise its security-holders to vote for or against the plan, depending upon its opinion of the plan's validity. The necessity of having control of the securities, or having them deposited with the committee, is therefore lessened. A proxy or authorization would seem, in most cases, to be sufficient. In addition, the function of "service" to its security-holders is not to be overlooked. A committee may be of great assistance in keeping its security-holders directly advised of proceedings, particularly as they affect their own interests (a function which the trustee seldom attempts to perform); in assisting the trustee, when asked to do so,

- Northern Pacific Ry. v. Boyd, 228 U. S. 482 (2913).

${ }^{20} 4$ I STAT. 494 (I920), 49 U. S. C. 5202. 
as to particular litigation; and in advising the trustee (again when asked) as to administrative matters.

In all this, there is an existing need for protective committees in reorganizations under Section 77 , but plainly it is a different need than under the equity receivership. This difference suggests that changes are required in the old mechanism by which the typical protective committees functioned, and, as.I will discuss later in this article, these changes are being recognized in practice.

\section{Methods of Representation Contemplated by Section 77 ( $p$ )}

Three typical means of representation for security-holders in a Section 77 proceeding are contemplated by sub-division (p)..$^{10^{*}}$ First, an individual may appear himself by counsel in the proceeding. Obviously, this method is of slight importance in a railroad reorganization where bonds are widely held and the expense of adequate representation in a protracted proceeding makes it almost prohibitive for any one but a very large holder to employ individual counsel. There are, however, 2 number of instances of the employment of this method.12 Second, groups of not more than 25 security-holders may act together for their own interest through representatives or otherwise. This method has been increasingly used, especially by life insurance companies and savings banks, whose important role in railroad reorganization is well recognized, with what implications on the general problem of security-holder 'representation I discuss below. Finally, regulated and authorized protective committees are recognized as a means of representation of securityholder interest in railroad reorganization in subdivision (p). Persons desiring to act as a protective committee must make application to the I. C. C. for authority to act. I have recently discussed elsewhere in some detail the meclianics of this regulation, the means whereby such authority is obtained, and the requirements which the Commission makes as to personnel, deposit agreements and authoriza.tions. ${ }^{2}$

One further implication of subdivision $(p)$ must be noticed: it contemplates that committees may seek deposits, or that they may solicit authorizations or proxies to act for security-holders. The suggestions implied in this provision are fruitful in their-bearing upon the new functions of the protective committee under Section 77 .

Two questions arise: (I) Are these methods provided by Section 77 affording adequate means for the representation of security-holders' interest? (2) Is the regulation of protective committees by the I. C. C. under Section $\eta 7$ achieving the results which the authors of subdivision $(p)$ apparently intended?

\footnotetext{
20: The role of the indenture trustee in representing security holders is not bere discussed parily because it is not a means of representation contemplated by subsection $(p)$ and partly because it is a separate problem, the adequate discussion of which is beyond the space limitations of this article.

${ }^{12}$ Notably the A. C. James Company in the Western Pacific Reorganization, Moody's MuNons, Run20108 (1939) 1733.

${ }^{21}$ Fennell, Protective Commitzees and Deposit Agreements in Railroad Reorganixations (1939) 49 YazX L. J. 224.
} 
Before considering these questions, let us contrast briefly regulation under Section $\pi(p)^{13}$ with regulation of committees in public utility reorganizations by the Securities and Exchange Commission under Sections II (g) and 12 (c) of the Public Utility Holding Company Act of $1935 .^{14}$

\section{Two Systems of Protective Commitree Regulatton}

The procedure for complying with the regulations of the I. C. C. ${ }^{15}$ is to file an application for authority to act with the Commission which contains information (as required by the Commission's rules) in regard to the committee's personnel, holdings of securities of the railroad in reorganization or in receivership by the member, his family and companies or firms with which he is connected; information about the committec's expected financing of expenses, and the form of deposit agreement or authorization under which the committee proposes to act. A hearing is held before an examiner of the Commission and thereafter the Bureau of Finance may, and usually does, suggest changes in the deposit agreement or authorization. On report and order the Commission may deny the application or grant it on terms, including always that the committee will abide by the Commission's rules and regulations, will keep minutes and records of actions taken, and file monthly reports of receipts and disbursements with the Bureau of Finance. Thereafter, if authority is granted, the committee may solicit deposits or authorizations, as the case may be.

The regulation of public utilities' committees under the rules of the S. E. C. is quite different. First, the solicitation of the deposit of securities is rarely possible because of the Commission's rule which limits that right to very unusual situations. ${ }^{16}$ Second, the rules require that a copy of a proxy statement must be filed with the Commission at least ten days before the committee expects to commence solicitation. ${ }^{17}$ The material in the proxy statement is much the same as that which must be contained in an application to the 1 . C. C. under Section $\eta 7$ (p), but the great difference is that this proxy statement is required to accompany any other information sent security-holders at the time they are solicited. If committee's counsel is well-advised, he will confer or correspond with the conferee in charge of considering the proxy statement, as suggestions are practically always made as to the information contained in it, and as to the advisability of including more. Furthermore, the authorization or proxy solicited must contain fair and equitable provisions for ${ }^{18}$ (a) a review and determination by the court, commission or an independent person of all fees and expenses to be paid by the estate or persons solicited; (b) submission of periodic statements of account to the persons solicited; and (c) the unconditional right to revoke or cancel the proxy at any time without

I2 C. C. H. BANX. SERv. \$7ror (1935).

14 C. C. H. SEC. ACT. SERV. $58402 \Lambda$ ff. (1937).

${ }^{23}$ See Fennell, supra note 12.

${ }^{18}$ Rule U-12E-3(c)(3)(A).

2* Rule U-r2E-3(e).

${ }^{10}$ Rule U-12E-3(2). 
expense. In addition, the committee becomes subject to the S. E. C.'s drastic "inside trading" rule which reads: ${ }^{19}$

the prohibition of the buying or selling, as principal, agent, trustee, or otherwise, or cauring another to buy or sell, or rendering any investment advice with respect to securities of the company or companies in reorganization, or of any subsidiary thereof, or of any other associate company thereof, the securities of which associate company may be affected by the reorganization, by or on behalf of any person effecting such solicitation, any person connected with any committee or other organization formed to act under the authorization so solicited, or any company as defined in section 2(a) of the Act which such person controls or of which such person is an offeer, director, partner or employes, or any individual who is a partner or employer of any such person;

The more important contrasts to the I. C. C.'s regulation under Section 77 are these: First, the information contained in the proxy statement (under the S. E. C. regulation) is made available directly to the security-holder; second, accounts, instead of being filed with the Commission, must be mailed to the security-holder; third, instead of fixing a limit in the agreement or authorization as to the maximum amount which security-holders may be charged for expenses, as in the I. C. C.'s procedure, the S. E. C. insists that all expenses (whether to be borne by the estate or the security-holders) must be approved by the court, Commission, or by an independent person; and fourth, the 1 . C. C. has frequently approved a requirement that a right to withdraw may be conditioned on payment of the pro rata expenses and accrued liabilities of the committee. ${ }^{20}$ Furthermore, while the I. C. C. has insisted on provisions in the deposit agreement or authorization prohibiting inside trading by members, ${ }^{21}$ it has never gone to the drastic, and, to my mind, impracticable, lengths of attempting to prohibit purchases or sales by "companies" with which members may be connected as required by Rule U-12E-3 (a) (C) quoted above, as applied by the S. E. C. to public utility committees. Such a rule is a deterrent to the employment of capable men to represent security-holders. The I. C. C. has wisely recognized that under certain circumstances even an underwriter or a person connected with an underwriter may be a legitimate and capable representative for security-holders. ${ }^{22}$

Another important difference is that the I. C. C. must afford a hearing on the application and must thereafter by order either authorize the committee or deny the application. The committee remains subject to the Commission's investigatory powers under subsection (p). There is no formal hearing under the S. E. C. procedure, but informal conferences have been found to be necessary to clear up questions of what the proxy statement should contain. Furthermore, since the proxy statement is not an application, and, in fact, the requirements of the rule are

20 Id. subsection (3) (C).

${ }^{20}$ See, e.g., deposit agreements approved in Missouri Pacific R. R. Reorg., 230 I. C. C. 377 (1939), and in Minneapolis \& St. L. R. R. Receivership, 233 I. C. C. 350 (1939).

"21 Missouri P2cific R. R. Reorg., 217 I. C. C. 671, 675 (1937).

${ }_{23}$ Missouri Pacific R. R. Reorg., supra note 20; 224 I. C. C. 405 (1938); and 230 I. C. C. 5 (1938); but see Chicago, I. \& L. Ry. Reorg, 221 I. C. C. 549 (1937). 
technically satisfied simply by filing the proxy statement, proxy, etc., the S. E. C. does not attempt to deny (nor does it grant) the right of the committee to act, but it may, if a rule is violated, attempt to keep the committee from being heard in the proceeding under Section $2 I_{3}$ of the Chandler Act (Chapter X, Bankruptcy Act) or it may object to any allowance to the committee under Section 247 of the Act. The S. E. C. may also attempt to limit the fees paid to the committee as to maximum amount under Section II (f) of the Public Utility Holding Company Act. False and misleading statements in the proxy statement will, of course, subject the committee to the liabilities of Section 18 of the Securities Exchange Act of 1934 by Section 16 (a) of the Holding Company Act.

On balance, I would say that the regulation of the I. C. C. under Section 77 is more realistic and more apt to be productive of good results, in providing adequate protection to security-holders, and without discouraging legitimate efforts, than is the S. E. C.'s regulation under the Holding Company Act. In fact, the drastic character of these regulations leaves it open to suspicion that the S. E. C. is trying to discourage all protective committee activity in fields where it has control. The one part of the S. E. C.'s procedure which the I. C. C. might adopt is the requirement of providing each security-holder solicited with something similar to the "proxystatement"--possibly a-brief summary of the more important information contained in the Committee's application so that he may be familiar with the qualifications, connections and holdings of the persons seeking to act for him.

\section{EFFECTS OF REgULATION UNDER.SECTION 77 (p)}

It is difficult (and perhaps too early) to appraise the effects of the regulation since 1935 by the I. C. C. of protective committees. That the regulations have not themselves been a deterrent to the use of the protective committee as a device for the representation of security-holders seems to be indicated by the fact that since the effective date of subdivision ( $p$ ) the I. C. C. (according to my count) has passed upon 27 applications ${ }^{23}$ of committees in ten reorganizations or receiverships. Complaint has been heard about the length of time, which it has taken in certain instances, to secure an order after the filing of the application and it is to be hoped that as the procedure becomes more settled that this time may be reduced.

Certainly the results of the regulation have been salutary from the standpoint of eliminating from deposit agreements and from the terms of authorizations provisions or practices which have been criticized. ${ }^{24}$ In 1937, Mr. Abe Fortas, then Assistant Director of the Protective Committee Study of the S. E. C, summarized the more important of these criticisms in a symposium in this periodical on the Securities Act. ${ }^{25}$ A comparison of these criticisms with the record of decisions of the I. C. C. on committee applications will show that in all important particulars the I. C. C. has achieved much.

23 Not including applications for approval of additional or substitute members.

21 I attempted to analyze these in the article cited in note 12, suprs.

"28 Fortas, supra note 4. 
1. Vesting Title to Deposited Securities in the Committee and Complete Domina. tion over Deposited Securities. ${ }^{28}$ The practice of taking title to deposited securities has not been frequent, in any event, in recent years, partly because of the lack of necessity for it, ${ }^{27}$ and also because of the stamp tax payable upon the transfer of title. ${ }^{28}$ Consequently, I know of no application where a committee has sought this right. I know that where a committee (which had functioned for a number of years and had long before making application taken title to deposited securities) sought authority to continue to act, the I. C. C. first took the position that the committee should not continue to have title to the deposited securities. ${ }^{29}$ In that instance, however, to insist on this view would have cost the depositors much in transfer stamp taxes, and the Commission therefore did not require the transfer of title back to the security-holders. So far as dominance over deposited securities is concerned, the Commission has been vigilant to protect security-holders. ${ }^{\mathbf{3 0}}$

2. Powver to Pledge Securities; Compensation and Expenses. ${ }^{31}$ The Commission has approved the fixing in the deposit agreement of a maximum amount for which deposited bonds may be pledged to secure loans to carry on the committee's activities. $^{32}$ There seems to me to be no room for criticism of this practice since the usual manner in which a committee taking deposits must raise funds to carry on is by the pledge of deposited bonds to secure loans. Since, under Section 77 (c) (12), members of committees are not entitled to compensation, Mr. Fortas's criticism in this respect does not arise at present as to railroad committees. Expenses of committees, including reasonable attorneys' fees, which are to be allowed from the estate must be fixed, as to maximum limits, by the Commission on special application and after hearing. The maximum amount of expenses for which the committee may charge depositing security-holders is fixed by the Commission on application of the committee for authority to act under Section 77 (p). Amounts approved in depesit agreements relating to bonds have varied from $0.3 \%$ s8 $3 \%^{34}$, and in the case of authorizations the Commission has approved the payment of a contribution at the time of solicitation and a balance, say, within six months. ${ }^{35}$ In other words, the regulation of committee financing has been reasonable without being drastic

Other criticisms offered by Mr. Fortas seem to have been met by I. C. C. decisions. Withdrawal rights have been protected, the Commission requiring the af-

*1d. at 237. "Sce my discussion at p. 475, suipra.

s* As to bonds, see INt. Rev. Coop, 53481, and U. S. Treas. Reo. 71. As ta stocks, see INT. Rev. CODE, 51802 (b) and U. S. Thens. REo. 71.

"Minneapolis \& St. I. R. R. Receivership, 233 I. C. C. 93 (1939).

${ }^{\circ}$ Chicago, M. St. P. \& P. R. R. Reorg., 228 I. C. C. 180 (1938); Chicago, R. I. \& P. Ry. Reorg.1 221 I. C. C. 435 (1937); Missouri Pacific R. R. Reorg, 230 I. C. C. $377,381,217$ I. C. C. 671, 674.

${ }^{21}$ Fortas, supra note 4 , 2t 237.

"22 Missouri Pacific R. R. Reorg., 221 I. C. C. 405 (1938); Chicago R. I. \& P. Ry. Reorg., 221 I. C. C. 435 (1937).

" Chicago, M. St. P. \& P. R. R. Reorg, 228 I. C. C. 180 (1938).

"Missouri Pacific R. R. Reorg., supra note 21.

"New York, N. H. \& H. R. R. Reorg, 224 I. C. C. 307, 310 (1937). 
fording of a right of withdrawal upon the adoption or amendment of a plan and upon the amendment of the deposit agreement. ${ }^{36}$ In the case of authorizations, it seems to have been usual to provide that they be revocable at any time. ${ }^{37}$ Provisions for the payment by depositors of their pro rata share of accrued liabilities and expenses to the date of withdrawal have been approved. There can, however, be no real objection to this, as it is only fair that the depositors should share the committee's expenses. It is only on the generally false assumption that the committee's activities have been of no benefit to the security-holder that this right can be denied. The I. C. C. has required that adequate standards for a final accounting must be provided, and that the right of any depositor, even one who has withdrawn, to file objections to the committee's final account be preserved.98 Exculpatory provisions have been scrutinized from the standpoint of fairness ${ }^{39}$ and provisions of deposit agreements permitting the underwriting by committee members of the new com. pany's bonds have been disapproved. ${ }^{10}$ So far as I know, no restrictions have been placed upon committee members becoming officers, directors or voting trustees of the new company, and there seems to be no reason why they should not be free to. since frequently committee members will be the persons best qualified to represent the securities on the new board. I have discussed above the I. C. C. requirements as to committee personnel and restrictions as to "inside trading" by committee members. ${ }^{41}$

\section{Solicitation of Authorizations}

One of the methods of security-holder representation contemplated by subdivision (p) is the solicitation of authorizations or proxies empowering the committee to appear in behalf of the security-holder in reorganization. This, we have seen, is the only practicable method now available in utility reorganizations.

How extensively has this device been used in railroad reorganizations since the I935 amendment was enacted? According to my count, in fifteen out of 27 applications to the Commission, the committee has sought permission to solicit authorizations or proxies rather than deposits. In nine of these applications the authorization sought was to represent bonds, in three, preferred stock and in three, common stock.42 Evidently, therefore, there is a definite trend in favor of soliciting authorizations.

What are the possible reasons for this trend and what is its effect on adequate representation of security-holder interests?

"New York, N. H. \& H. R. R. Reorg. 217 I. C. C. 60 (1936); Missouri Pacific R. R. Reorg, supre note 20.

${ }^{27}$ Cf. New York, N. H. \& H. R. R. Reorg., 224 I. C. C. 423,426 (1938).

"see e.g., Missouri Pacific R. R. Reorg., 230 I. C. C. $377,383$.

"Implied in Missouri Pacific R. R. Reorg., 217 I. C. C. $671,675$.

${ }^{10}$ Utah Idaho Central R. R. Reecivership, 236 I. C. C. 235,239 (1939).

¿Sce p. 478, supra.

"In three recent cases in the advance sheets of the $I$. C. C. reports the committees sought and obtained authority to solicit proxies or authorizations. See Floridz East Coast Ry. Receivership, 236 I. C. C. 737 (1940); New York, N. H. \& H. R. R. Reorg,, 236 I. C. C. 797 (1940), and Erie R. R. Reorg, 239 I. C. C. 213 (1940). 
A few reasons may be suggested. The expense of handling deposited securities is in itself a reason for preferring the proxy solicitation. If a commitce takes deposits, certificates of deposit must be prepared, and while a committce complying with Section 77 (p) is exempt from registration under the Securities Act, ${ }^{43}$ if the certificates are listed on a national sccuritics exchange, registration under the Exchange Act will be necessary. In addition to these cxpenses and problems, the committee must provide a depositary, and unless the transfers are to be handled by the depositary, a transfer agent. In connection with all this, the committee's legal expenses will be materially increased. The deposit agreement itself is a much more complicated and claborate document than the authorization or proxy which again means more legal work and expense. Tax questions are more apt to arise, generally requiring the advice of counsel, where certificates of deposit are used.

But is the committee, whose authority stems from proxies rather than from deposits, in as effective a position to represent the security-holder in the reorganization? True, at any time after the authorization has been given, the security-holder may sell his holdings without notifying the committee. ${ }^{41}$ As a consequence, there is no question that, to this extent at least, the committce with proxies is not as sure of the number of security-holders for whom it is authorized to speak. However, this can be minimized by fairly frequent communications to security-holders and requests to notify the committee of such transfers. The security-holders' lists may be examined so that the transferee in turn may be solicited. For all practical purposes, it seems that such a committee may be as influential and effective as a committee with deposits, and at less expense.

I have pointed out that the functions of a protective committce have changed by reason of the change in the mechanism of reorganization. The plan will be submitted by the Commission to the security-holders for a vote and at that time the committee with authorizations may recommend to its security-holders action which it thinks should be taken. It is a close question whether even a committee with deposited securities will be permitted to vote them in block for or against the Commission's plan. ${ }^{45}$ Certainly it cannot do this except after affording a right of withdrawal to dissenting depositors. ${ }^{48}$ Thus, the position of the two types of committees is equalized in large measure. Among non-institutional groups of security holders it may be expected that the solicitation of authorizations or proxies will find continuing favor.

${ }^{43}$ Bankruptcy Act, 577 , subsection (f) (4).

"Cf. New York, N. H. \& H. R. R. Reorg., 224 I. C. C. 423,426 (2938).

${ }^{46}$ Section $77(e)$, zelating to the acceptance or rejection of a plan provides in part: "For the purpose of this section the acceptance or rejection by any creditor or stockbolder shall be in writing, executed by him or by his duly authorized attorney, committee, or representative." If an suthorized commintee has adopted a plan, identical with that proposed by the Commission, and has aftorded a right of withdrawal to depositors, it seems that, if the deposit agreement grants such authority, the committee should be able under the stanute to vote for the assenting bondholders in favor of the plan.

${ }^{10} \mathrm{New}$ York, N. H. \& H. R. R. Reorg., 217 1. C. C. 60 (1936); Missouri Pacific R. R. Reorg., 230 I. C. C. $377(1938), 224$ I. C. C. $405(1938)$. 


\section{"Groups" for Security-Holder Representation}

Without attempting to exactitude, it is safe to say that as the pattern of securityholder representation is changing as to non-institutional investors by the use of the device of proxy solicitation, so it is changing by the increasing use of the "group" device by institutional investors, life insurance companies and savings banks.

As we have seen, subdivision (p) permits a group of not more than 25 holders to be represented in the proceeding without compliance with the protective committee provisions of subdivision (p) and the I. C. C.'s regulations pursuant thereto. It is significant that since this provision was enacted, in practically every important railroad reorganization, there has been one or more "institutional groups" representing in the aggregate large amounts of bonds owned by life insurance companies or savings banks. This is true in the New Haven, the Erie, the Denver \& Rio Grande, the Chicago, Northwestern, the Western Pacific and the St. Paul reorganizations. When it is realized that in prior reorganizations many of these same institutions assumed and supplied the necessary leadership for, and, in many cases advanced the money to pay the expenses of, protective committees to which large and small depositors were welcomed, as, for example, in the Missouri $\mathrm{Pa}$ cific, Rock Island, Chicago \& Eastern Illinois, the Monon, Spokane International, the Frisco, the Central of Georgia, and the Wabash-some interesting questions as to our problem are presented.

From the standpoint of the institutional holder, the attractiveness of the group is obvious. No application to the I. C. C. for authority to act is required. No solicitation of deposits need be made, no security registration is necessary, and no responsibility need be taken for representing the interests of other security-holders. The possibility of public criticism is lessened if things go wrong, because the institutions are acting only in their own behalf to protect their own securities. The small compact group can more easily arrive at conclusions of policy which will not be sniped at by the small holder, cxcept in opposition to action taken before the court or Commission. Until the group provisions of Section 77 (p) provided an alternative, the protective committee afforded the only effective mode of action for the institutions to take. And in connection with such committees, the institutions frequently have borne the brunt of the expenses. This tendency is succinctly illustrated in the Commission's report on the application of the Alsop Committee in the Chicago, Indianapolis \& Louisville Ry. Co. Reorganization ${ }^{47}$ for authority to represent holders of first and general mortgage bonds. It appears from the report that the Guaranty Trust Company of New York, as trustee of the mortgage, called a meeting to consider the debtor's plan which was attended by about fifty bondholders. A temporary committee was appointed to report whether a committee should be organized.

This report was submitted to a second meeting of the bondholders held at the offices of the Guaranty Trust Company of New York on January 7, 1937. It developed at this meeting that none of the members of the temporary committee, with the exception of

4221 I. C. C. 549 (1937). 
Alsop and Dodge, was willing to act upon a committee for holders of these bonds generally. The members of the temporary committec who were unwilling to act were affiliated with life-insurance companies and savings banks owning substantial amounts of these bonds, and it was their opinion they could better protect their policy holders and depositors by acting either separately or in groups of not more than 25 as permitted under section $77(\mathrm{p})$ of the Bankruptcy Act. One of these members, representing a life-insurance company holding $\$ 704,000$ of these bonds and believing that a committec should be formed to represent bondholders generally, based his refusal to act on such a committee on his experience as a member of a protective committee where the large institutions had to bear most of the expense and where an insurance company was compelled to refuse an offer for the purchase of its bonds, the value of which became much less later, because such offer was not made for every bond represented by the committec. ${ }^{48}$

What has been the effect on the small non-institutional holder of this tendency of the large institution to join a group rather than to organize a committee in which the small holder might also participate? This is difficult to answer, and it is probably too early to draw conclusions. From one standpoint it might be argued that the small holder benefits (without paying for it) by reason of the group's gratuitous representation of his security. And to a large extent this is probably true. Furthermore, it is undoubtedly true that institutions, having played the role of "angel" to protective committees, are glad of a means to avoid the role in the future.

But the plight of the non-institutional security-holder may become acute if we do not assume that the group representing his issue will always act to protect the noninstitutional holders' interest. Now that the group device is being more commonly employed, the problem of securing leadership in forming protective committees for the other holders is obviously more pressing. Thus, among the reasons advanced by the Kann Committee for authority to represent the first and refunding bonds, and $4 \%$ Debentures of the New Haven, and the $4 \%$ Debentures of the Providence Securities Company, was that the only other representatives of the securities were institutional groups and that the other bondholders needed the committee's representation in the proceeding. ${ }^{49}$ It is impossible to appraise the effect of this change on the general problem of representation until greater experience has been had with the group device.

\section{Conclusions}

The regulation of protective committees under Section $77(\mathrm{p})$ compares favorably to the regulation of public utility committees under the Holding Company Act in results achieved and in insuring adequate representation of security-holder interests. The changes which are taking place in the techniques of representation show a realistic adjustment to the new functions of protective committees under the procedure of Section 77. It is significant that neither the Wheeler ${ }^{50}$ nor Chandler bills, ${ }^{51}$ which

4I. $550-55 \mathrm{~T}$.

4 New York, N. H. \& H. R. R. Reorg., 224 1. C. C. $423,424$.

${ }^{80}$ S. 1869, 76th Cong. Ist Sess. (1939); $c f$. Lea Bill, H. R. 4862, 76th Cong. 1st Sess. (1939).

${ }^{81}$ Suggested form of composite bill as an alternative to S. 1869, H. R. 6369 , and Tite $V$ of H. $R$ 4862; prepared after analysis of hearings on S. 1869, and containing explanatory notes for the use of the Committee on the Judiciary. 
would make other substantial changes in railroad reorganizaticn, propose any change in the provisions of Section 77 regulating committees, save the one discussed below.

One important change would be made, however, by both of these bills ${ }^{52}$-that is, to restore to protective committee members the right (which before 1935 Section 77 afforded them) $)^{53}$ to receive reasonable compensation for their services. At present committee members are entitled only to reimbursement of reasonable expenses, including reasonable attorney's fees. ${ }^{\text {.4 }}$ If protective committees are necessary, as they are in Section 77 reorganizations, and if adequate leadership is to be attracted (particularly in view of the group competition that I have described), it is essential, in my opinion, to allow reasonable compensation to committee members for services rendered. The unfairness of not permitting committee members to have compensation is emphasized by the present provisions of Section 77 (c) (12) which permit indenture trustees and depositaries to be compensated. In almost every reorganization, it is common knowledge that it is a committee and not the indenture trustee which carries the burden of representation. ${ }^{5 \delta}$ Yet at present the trustee may be compensated and the committee may not be. This should be remedied in either the manner contemplated by the Wheeler Bill ${ }^{56}$ or by the Chandler Bill. ${ }^{57}$

In a word, the regulation of protective committees in railroad reorganizations by the I. C. C. has gone far to meet legitimate criticisms and to afford adequate representation of security-holders' interests, and, on the whole, has. been reasonable and praiseworthy.

82 Wheeler Bill, supra note 48, \$(c)(12), at p. 35; Chandler Bill, supra note 49, 598z, at p. 76 .

sa Bankruptcy Act, $\$ 77$ (b)(8) (prior to 1935 amendments).

"Bankrupicy Act, 577 (c)(12).

${ }^{85}$ In line with the condusion reached by the S. E. C.'s Protective Committee Study that indenture trustces "be transformed into active trustees" (see SEC, REPORT PURsuant to \$II OF THE SEcurmes Exchange ACT of 1934, Pt. VI, "Trustees Under Indenkures," (1935)) there have been recent instances of indenture trustees taking an active role in representing security holders' interests in reorganizations, notably in the Erie.

so The Wheeler Bill provides (5(c)(12)) that "reasonable compensation . . for services rendered in the interest of and with benefit to the estate as a whole, and ant exclusiveiy in the interest of a parcicular class" by a committee may be allowed by the court from the estate of the debtor. Services not for the benefit of the estate but in the interests of a class of security holders may be compensated by imposing a lien on the securities to be distributed under the plan to the benefitted class, and the order may provide for the distribution of 3 proportion of such securities in satisfaction of the allowance.

${ }^{87}$ The Chandler Bill (\$982) would make the provisions for allowances to committees for compensation and reimbursement of expenses in essential respacts the same as the similas provisions of Chapter $\mathbf{X}$. 